\title{
Elastomers for maxillofacial applications
}

\author{
R.G. Craig, A. Koran and R. Yu \\ School of Dentistry, The University of Michigan, Ann Arbor, Michigan 48109, USA \\ (Received 26 November 1979; revised 8 February 1980)
}

Systematic evaluations of the properties of prosthetic facial materials began to appear in 1969 with a report by Cantor et al. ${ }^{1}$ They reported that plasticized poly(methyl methacrylate) was the best material with respect to resistance to tearing and degree of elongation. A year later, Walter ${ }^{2}$ reported the specific gravity, water sorption, thermal conductivity, strain in compression, and permanent deformation on an acrylic ester resin, two silicone rubbers and a pourable latex rubber. The laboratory results and clinical trials indicated that the high compressibility and good tissue compatibility of the acrylic polymer made it the choice over the other elastomers.

In 1971, Roberts ${ }^{3}$ published the physical properties of a heat-cured silicone material and two room-temperature cured silicone elastomers and found tensile strengths from $300-1000 \mathrm{lbs} / \mathrm{in}^{2}$, ultimate elongations from $100-350 \%$, tear strengths from $20-100 \mathrm{lbs} /$ in and hardnesses from 45-50 Shore A numbers. The following year, Sweeney et al. ${ }^{4}$ determined the properties of a poly(vinyl chloride) maxillofacial material and proposed a set of requirements for such materials including an accelerated aging test for evaluating changes in colour but not mechanical properties.

In 1973 a symposium was held to discuss priorities in dental biomaterials research ${ }^{5}$. At that symposium Castleberry 6 discussed the choices and challenges of materials for external maxillofacial prostheses. Materials reviewed at that time were poly(vinyl chloride), heat- and room-temperature cured silicones, silphenylene [poly (silphenylenedimethylsiloxane)], and polyurethanes.

The next year, Lontz et al. ${ }^{7}$ reported how the properties of polysiloxanes could be modified by oils and crosslinking agents to approximate the stress-strain profiles of human tissues such as aorta and tendon.

Since 1974 there has been a significant increase in research on maxillofacial materials by Koran and Craig ${ }^{8}$ Goldberg et al. ${ }^{9-11}$, Yu et al. ${ }^{12}$, May et al. ${ }^{13}$, Gonzalez ${ }^{14}$. and Koran and co-workers ${ }^{15-20}$. It is the purpose of this paper to review the developments of maxillofacial materials in the 1970's.

\section{REVIEW}

A number of authors have listed the qualities of an ideal maxillofacial material which can be summarized as: (1) having original physical and mechanical properties comparable to human tissue they are replacing, (2) main- taining these properties during service, (3) being compatible with human tissues and adhesives used to adhere the prostheses to tissues, and (4) being easy to process and insensitive to processing variables.

The stress-strain properties of muscle have been studied by King and Lawton ${ }^{21}$ and Sten-Knudsen ${ }^{22}$. It has been found that the stress per unit of strain was low and nonlinear as well as being more viscous than elastic with the stress-strain curve showing hysteresis. Lontz et al. ${ }^{7}$ utilized the above properties of muscle as a basis for modifying a silicone elastomer with oils and crosslinking agents to match the stress-strain properties of tissue in the low strain regions. The information on the viscoelastic properties of soft facial tissues is limited and substantial improvement in its characterization is important in the development of maxillofacial materials.

Until recently only modest efforts had been made in the characterization of the colour parameters of human facial skin. Recently Koran et al. ${ }^{18}$ measured the colour of 195 whites, 22 blacks and 24 orientals using reflection spectrophotometry. Average reflectance versus wavelength curves for these three groups are shown in Figure 1 and the

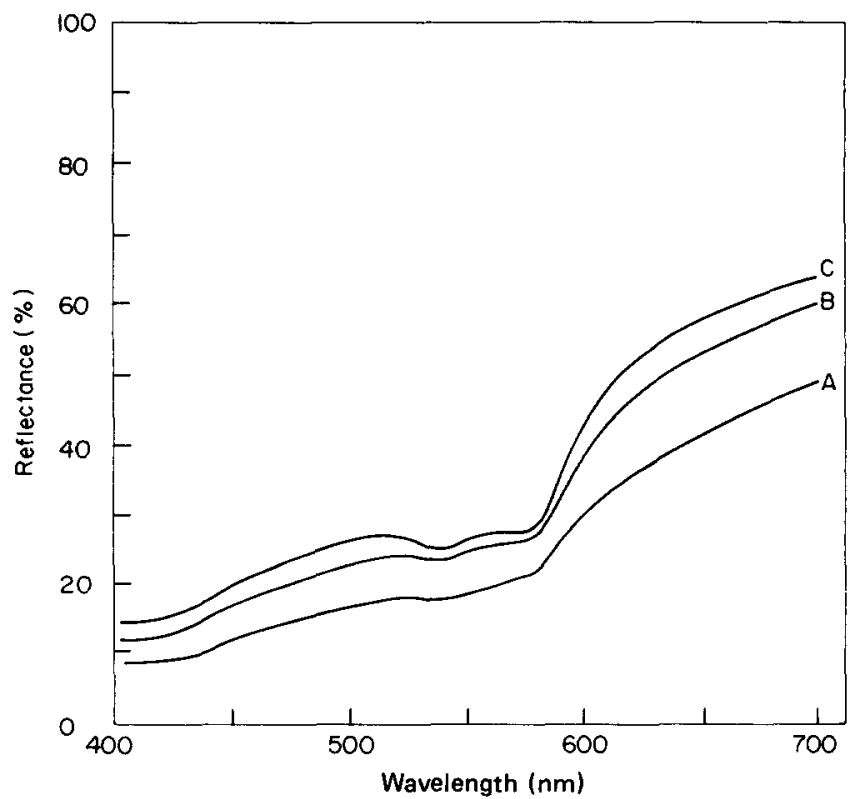

Figure 1 Mean reflectance curves for $A$, black, $B$, oriental, and $C$ white population groups. (Adapted from Koran $A$. Powers, J.M. Raptis, C.N. and Yu, R., J. Dent. Res. Spec. Iss. A, 1979, 58, 360). 
calculated values for luminous reflectance, dominant wavelength and excitation purity are listed in Table 1. The wide range of skin colour in each group is indicated by the large standard deviations for luminous reflection and excitation purity. The two peaks at 540 and $580 \mathrm{~nm}$ represent the absorption of oxyhaemoglobin and are more pronounced in whites with high values for luminous reflectance and low excitation purity. The curve is lower for orientals and blacks than for whites probably because of greater concentrations of melanin. It is interesting that only minor variations occurred in the dominant wavelength for the three groups. Information of this type is needed for patients who require maxillofacial prostheses, in order to improve the probability of obtaining a proper colour match between the face and the material.

Table 1 Colour parameters for human skin with light source $C$

\begin{tabular}{llll}
\hline & $\begin{array}{l}\text { Luminous } \\
\text { reflectance }\end{array}$ & $\begin{array}{l}\text { Dominant } \\
\text { wavelength, nm }\end{array}$ & $\begin{array}{l}\text { Excitation } \\
\text { purity }\end{array}$ \\
\hline Blacks & $21.9(7.6)^{*}$ & $588.0(1.9)$ & $0.360(0.051)$ \\
Whites & $30.9(5.0)$ & $590.7(3.0)$ & $0.287(0.036)$ \\
Orientals & $28.4(4.0)$ & $588.4(2.1)$ & $0.320(0.028)$ \\
\hline
\end{tabular}

* Standard deviations in parentheses.

\section{Types of maxillofacial polymers}

Commercial and experimental materials include poly(methyl methacrylate), poly(vinyl chloride), chlorinated polyethylene, polyurethanes, and silicones.

Rigid poly (methy/ methacrylate) is still used for facial parts such as eyes but the material is hard and does not have an appearance of skin. Low molecular weight oily esters such as the phthalates have been used to plasticize poly (methyl methacrylate) but migration and absorption of stains by the plasticizer are some of the problems with this material and its use as an elastomer is limited. The materials are readily processed in gypsum moulds using standard dough moulding procedures.

Poly(viny/ chloride) is a stiff plastic with a glass transition above room temperature and must be highly plasticized for maxillofacial applications. The polymer yellows on exposure to ultraviolet light and stabilizers must be added in order to minimize colour changes on aging. The polymer is supplied as a finely divided solid suspended in a solvent which when heated results in a sol that gels to an elastomer upon cooling. The processing conditions are critical if optimum properties are to be obtained and the processing temperature indicates the use of metal moulds.

Polyurethanes are polymers produced by the reaction of diisocyanates and polyols. The components are selected such that an elastomer results and the final polymer may contain polyester, polyether, aromatic and/or aliphatic groups. The polyol may be di- or tri-functional depending on whether crosslinking is desired and may be a polyether or polyester macroglycol. The diisocyanate may be either an aliphatic (e.g. hexamethylene diisocyanate) or an aromatic (e.g. tolylene diisocyanate) compound although the former are inherently more stable to ultraviolet light and hydrolytic degradation. The reaction rate may be increased by the use of a curing agent such as stannous octoate. Finally, both ultraviolet light stabilizers and antioxidants may be included. It is apparent that a wide variation in properties may be obtained by the selection of components used to make up the polyurethane. Care must be exercised in the handling of the toxic diisocyanates and the polymerization must be conducted under dry conditions or carbon dioxide will be produced resulting in a porous prosthesis. Processing temperatures of about $100^{\circ} \mathrm{C}$ allow the use of stone moulds which are more convenient than metal moulds. Finally, since the reaction is stoichiometric the components must be accurately dispensed especially since no extra reactive functional groups are desired in the final polymer.

Silicones of four types have been used commercially or experimentally for maxillofacial materials. Dimethylsiloxane (S-44515) may be vulcanized by heat by using an organic peroxide. This material is cured at $100^{\circ} \mathrm{C}$, postcured at $160^{\circ} \mathrm{C}$ and metal moulds are used. The material is supplied as a high viscosity, rubbery solid and pigments are incorporated using a three-roll rubber mill.

Dimethyl siloxanes (S-382 and 399) having terminal hydroxy groups are available that are polymerized using a stannous octoate catalyst and an orthoalkyl silicate crosslinking agent by a condensation reaction. A highly crosslinked silicone results plus a low molecular weight alcohol from the condensation reaction. Polymerization occurs at room temperature and processing is simple and can be accomplished in gypsum moulds. Microfine silica is used as a filler to improve the physical and mechanical properties.

Dimethylsiloxanes also are available that polymerize by an addition reaction ( $S-44210$ ). A vinyl terminal siloxane and a silane terminal siloxane are polymerized using a chloroplatinic acid catalyst. The processing is simple and is accomplished at room temperature. These materials also contain microfine silica as a reinforcing agent.

Silphenylene has been used experimentally and is a siloxane copolymer containing methyl and phenyl groups. It is polymerized by a catalyst system similar to $\mathrm{S}-382$ and 399. The material is non-toxic, can be processed in gypsum moulds, may be polymerized from $25-100^{\circ} \mathrm{C}$, and has a working time at room temperature of $5 \mathrm{~min}$.

A chlorinated polyethylene also has been developed for use as a maxillofacial material and it has been used clinically. The material may be compounded with other polymers and with pigments on a heated rubber mill and processed in metal moulds at $190^{\circ} \mathrm{C}$ for $15 \mathrm{~min}$ to produce a prosthesis.

\section{Mechanical properties}

The original static mechanical properties of commercial and experimental maxillofacial materials are listed in Table 2. The properties after accelerated aging for $900 \mathrm{~h}$ are also given.

In general the heat vulcanized silicones, the experimental polyurethane and the chlorinated polyethylene had the highest mechanical properties followed by the addition polymerized silicone and the poly(vinyl chloride) and finally the commercial polyurethane. The commercial polyurethane was processed according to the manufacturers directions. Gonzalez ${ }^{14}$ has shown that wide variations in properties can be obtained with this urethane by altering the ratio of polyol and diisocyanate and the processing conditions. For example, increasing the diisocyanate component from 11.8 to $13.0 \%$ by weight increased the 
Table 2 Mechanical properties of polymers for maxillofacial applications

\begin{tabular}{|c|c|c|c|c|c|c|}
\hline & $\begin{array}{l}\text { Ultimate tensile } \\
\text { strength, } \mathrm{kg} / \mathrm{cm}^{2}\end{array}$ & $\begin{array}{l}\text { Maximum } \\
\text { elongation, \% }\end{array}$ & $\begin{array}{l}\text { Shear strength, } \\
\mathrm{kg} / \mathrm{cm}^{2}\end{array}$ & $\begin{array}{l}\text { Tear energy, } \\
\text { ergs } / \mathrm{cm}^{2} \times 10^{6}\end{array}$ & $\begin{array}{l}\text { Tear strength } \\
\mathrm{kg} / \mathrm{cm}\end{array}$ & $\begin{array}{l}\text { Hardness } \\
\text { shore A-F }\end{array}$ \\
\hline \multicolumn{7}{|l|}{$\begin{array}{l}\text { Poly(vinyl chloride) } \\
\text { (Prototype III) }\end{array}$} \\
\hline Original & 40.7 & 215 & 20.5 & 4.28 & 8.9 & 53 \\
\hline Aged 900 hours ${ }^{a}$ & 36.2 & 200 & 16.9 & 3.97 & - & 57 \\
\hline \multicolumn{7}{|l|}{$\begin{array}{l}\text { Polyurethane } \\
\text { (Epithane) }\end{array}$} \\
\hline $\begin{array}{l}\text { Original } \\
\text { Aged } 900 \text { hours }\end{array}$ & $-^{8.5}$ & $\begin{array}{l}420 \\
- \\
b\end{array}$ & $\begin{array}{l}15.2 \\
-b\end{array}$ & $\begin{array}{l}6.67 \\
-b\end{array}$ & $-b$ & $\begin{array}{c}6 \\
-b\end{array}$ \\
\hline \multicolumn{7}{|l|}{ (Experimental)c } \\
\hline Original & 112 & 500 & - & 19 & - & - \\
\hline \multicolumn{7}{|l|}{$\begin{array}{l}\text { Silicone } \\
\text { (Silastic 44210) }\end{array}$} \\
\hline $\begin{array}{l}\text { Original } \\
\text { Aged } 900 \text { hours }\end{array}$ & $\begin{array}{l}42.8 \\
39.0\end{array}$ & $\begin{array}{l}445 \\
400\end{array}$ & $\begin{array}{l}24.6 \\
24.5\end{array}$ & $\begin{array}{l}-d \\
-d\end{array}$ & $\begin{array}{l}16.1 \\
-\end{array}$ & $\begin{array}{l}32 \\
33\end{array}$ \\
\hline \multicolumn{7}{|l|}{ (Silastic 44515) } \\
\hline Original & 59.8 & 440 & 26.8 & $-d$ & - & 45 \\
\hline Aged 900 hours & 63.2 & 490 & 26.2 & $-d$ & - & 45 \\
\hline \multicolumn{7}{|l|}{ (Silphenylene) } \\
\hline Original & 98.4 & 1000 & - & - & 1.6 & 35 \\
\hline \multicolumn{7}{|c|}{$\begin{array}{l}\text { Chlorinated polyethylene } \\
\text { (GSR 1-1) }\end{array}$} \\
\hline Original & 94.6 & 975 & - & - & 18.8 & 47 \\
\hline Agede & 84.4 & 950 & - & - & 13.4 & 42 \\
\hline
\end{tabular}

aWeather-Ometer with a 2500 watt Xenon light source with a borosilicate filter to produce an energy spectrum similar to natural sunlight. Water spray was used 18 of every 102 minutes at H.H. of $90 \%$ and temperature of $43^{\circ} \mathrm{C}$.

bAging discontinued after $300 \mathrm{~h}$ because of degradation of samples.

CAn aliphatic polyether urethane with an average molecular weight per crosslink of $12900 \mathrm{~g} / \mathrm{mole}$ and an $\mathrm{OH} / \mathrm{NCO} \mathrm{ratio}$ of 1.1 .

dSamples did not tear but extended as in tensile.

e Aged on rooftop in New Orleans from February to May 1977.

Shore A hardness from 7 to 35 . It appears that the manufacturers ratio causes sufficient unreacted hydroxy groups that a soft urethane results and that increasing the diisocyanate component results in a more satisfactory stoichiometry and a harder urethane polymer. Care must be exercised in proportioning since excess isocyanate groups are undesirable. These results emphasize the critical nature of the proportioning in the processing of urethanes.

The commercial urethane degraded during aging to the point where the material lost its shape after $300 \mathrm{~h}$ and thus no mechanical properties after $900 \mathrm{~h}$ of aging are reported. The experimental urethane, however, showed no change in tensile strength after 10 weeks in water at $70^{\circ} \mathrm{C}$; it also had three times the tear energy after processing compared with the commercial polyurethane.

The silicone materials had minor changes in mechanical properties with the poly (vinyl chloride) and the chlorinated polyethylene showing greater changes. However, except for the commercial polyurethane aging of the polymers does not appear to be a serious problem with respect to mechanical properties.

The dynamic mechanical properties of selected maxillofacial materials have been reported only recently by Koran and $\mathrm{Craig}^{8}$. The dynamic modulus determined at a resonant frequency of 60 c.p.s. is plotted as a function of temperature for four materials in Figure 2. The dynamic modulus of all but the room-temperature vulcanized silicone (399) showed a transition at about $0^{\circ} \mathrm{C}$ with an increase in the rate of change at temperatures below this value. The rate of increase below $0^{\circ} \mathrm{C}$ was greatest for the poly(vinyl chloride) followed by the polyurethane and the heat-vulcanized silicone (44515). The rapid increase in dynamic modulus with decreasing temperature for the poly (vinyl chloride) is a drawback for its use in temperate climates.

The fatigue properties of selected maxillofacial materials are listed in Table 3. The samples were strained from 0 to $100 \%$ at 60 cycles per minute and the number of cycles to failure was determined. The values for polyurethane have been confirmed by Goldberg ${ }^{9}$ who reported about 10000000 cycles to failure for a polyether-aliphatic urethane with an average molecular weight between cross.

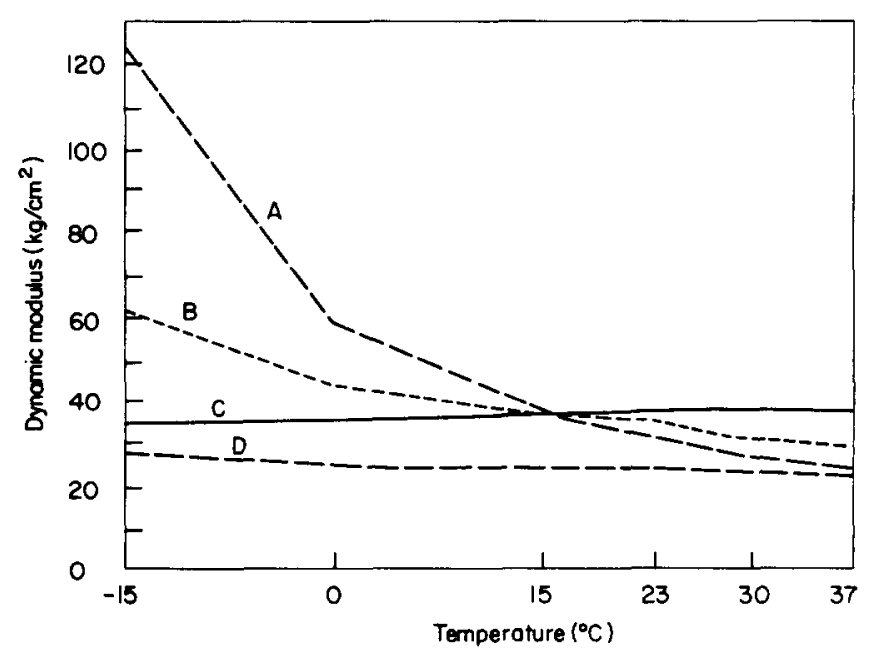

Figure 2 Dynamic modulus as a function of temperature for poly (vinyl chloride) A, polvurethane B, and silicone (Silastic $399 \mathrm{C}$ and 44515 D) maxillofacial materials. (Adapted from Koran, A. and Craig, R.G., J. Dent. Res. 1975, 54, 1216). 
links of 12900; these samples were strained from 50 to $150 \%$ at 40 cycles per minute. It is apparent that all of the materials except the polyvinyl chloride have acceptable flexural fatigue life.

Again it should be emphasized that insufficient information is available on the static and dynamic properties of human facial tissues to attempt to match these properties with those of maxillofacial materials.

Table 3 Flexural fatigue life of maxillofacial materials

\begin{tabular}{cc}
\hline Material & $\begin{array}{l}\text { Number of } \\
\text { cycles at failure }\end{array}$ \\
\hline $\begin{array}{l}\text { Poly (vinyl chloride) } \\
\text { (Prototype III) }\end{array}$ & 9000 \\
$\begin{array}{c}\text { Polyurethane } \\
\text { (Epithane) }\end{array}$ & 9500000 \\
$\begin{array}{c}\text { Silicone } \\
\text { (Silastic 382) } \\
\text { (Silastic 399) } \\
\text { (Silastic 44210) } \\
\text { (Silastic 44515) }\end{array}$ & 7300000 \\
\hline
\end{tabular}

\section{Physical properties}

Changes in the appearance of maxillofacial prostheses in clinical service suggested that changes in the colour of the polymers may be a significant concern. The colour stability of selected commercially available maxillofacial materials was determined recently by Craig et al. ${ }^{16}$ The luminous reflectance (comparable to value), dominant wavelength (comparable to hue), and excitation purity (comparable to chroma) were determined after processing and after $900 \mathrm{~h}$ of accelerated aging. These three parameters were determined using a reflection spectrophotometer with the sample against a black and white background. Small but significant changes occurred in luminous reflectance after aging for poly(vinyl chloride) with a black background and Silastic 44515 with a white background. A large increase in dominant wavelength resulted from aging the polyurethane for $300 \mathrm{~h}$ (yellowing observed with a black background) and a large decrease occurred for poly (vinyl chloride) after $900 \mathrm{~h}$ of aging (bleaching of the yellow). The remaining changes on aging for $900 \mathrm{~h}$ were slight or not significant.
The results for excitation purity indicate the intensity of colour with higher numbers representing more colour. The low values in Table 4 illustrate the low intensity of colour of the polymers used in maxillofacial prostheses. The decrease in excitation purity for poly (vinyl chloride) shows that a loss of colour occurred on aging for $900 \mathrm{~h}$ while the increase for the polyurethane after $300 \mathrm{~h}$ indicated an increase in colour. Significant but small changes in excitation purity were observed for the silicone materials after $900 \mathrm{~h}$ of aging. The contrast ratio is the ratio of the luminous reflectance with a black background to that of a white background. A ratio of zero represents a transparent material and a ratio of one is a completely opaque material. As seen in the footnotes of Table 4, Silastic $\mathbf{4 4 5 1 5}$ was more opaque than the polyurethane and Silastic 44210 , while aging affected the contrast ratio only of poly (vinyl chloride). These data indicate that the overall colour changes in the basic polymers of maxillofacial materials are minor especially when the practical problems of maintaining aesthetics clinically are considered.

The effect of accelerated aging on the colour of pigmented silicone is shown in Table 5 . The addition silicone (Silastic 44210) was selected for evaluation because of its overall superiority in colour stability compared with other materials. The changes in luminous reflectance, dominant wavelength and excitation purity were measured with 11 different pigments at a concentration of $0.2 \%$ by weight after $900 \mathrm{~h}$ of accelerated aging. The main changes in the pigmented samples occurred in those containing yellow, orange yellow, white, and light orange with small or insignificant changes observed for the other colours. Improvement in white and yellow pigments could contribute to improved colour stability of maxillofacial prostheses and a report by Seluk et al. ${ }^{21}$ showed that colour stability of pigments could be improved by sintering them in glass and using the ground glass for pigmentation. However, the changes in colour as a result of pigments were generally small and again could not explain the degree of colour change observed clinically.

From the two previous studies it appeared that the degree of the colour change observed clinically in maxillofacial prostheses may result from staining rather than aging of the polymers or pigments. The stain resistance of a poly-

Table 4 Colour stability of maxillofacial polymers using accelerated aging

\begin{tabular}{|c|c|c|c|c|c|c|c|}
\hline & \multirow[t]{2}{*}{ Background } & \multicolumn{2}{|c|}{ Luminous reflectance } & \multicolumn{2}{|c|}{ Dominant wavelength } & \multicolumn{2}{|c|}{ Excitation purity } \\
\hline & & on & $900 \mathrm{~h}$ & Oh & $900 \mathrm{~h}$ & $\mathrm{Oh}$ & $900 \mathrm{~h}$ \\
\hline $\begin{array}{l}\text { Poly (vinyl chloride) } \\
\text { (Prototype (II) }\end{array}$ & $\begin{array}{l}\text { Black } \\
\text { White }\end{array}$ & $\begin{array}{r}7.1 \\
66.7\end{array}$ & $\begin{array}{l}10.3 \\
62.9\end{array}$ & $\begin{array}{l}581.4 \\
584.0\end{array}$ & $\begin{array}{l}501.4 \\
583.8\end{array}$ & $\begin{array}{l}0.252 \\
0.552\end{array}$ & $\begin{array}{l}0.020 \\
0.198\end{array}$ \\
\hline $\begin{array}{l}\text { Polyurethane } \\
\text { (Epithane) }\end{array}$ & $\begin{array}{l}\text { Black } \\
\text { White }\end{array}$ & $\begin{array}{r}6.2 \\
79.6\end{array}$ & $\begin{array}{l}6.3^{e} \\
69.6\end{array}$ & $\begin{array}{l}545.0 \\
583.2\end{array}$ & $\begin{array}{l}573.2^{\mathrm{e}} \\
584.0^{\mathrm{e}}\end{array}$ & $\begin{array}{l}0.008 \\
0.112\end{array}$ & $\begin{array}{l}0.026^{\mathrm{e}} \\
0.164^{\mathrm{e}}\end{array}$ \\
\hline $\begin{array}{l}\text { Silicone } \\
\quad \text { (Silastic } 44210)^{\mathrm{C}}\end{array}$ & $\begin{array}{l}\text { Black } \\
\text { White }\end{array}$ & $\begin{array}{r}6.7 \\
69.9\end{array}$ & $\begin{array}{r}6.7 \\
78.3\end{array}$ & $\begin{array}{l}487.0 \\
586.0\end{array}$ & $\begin{array}{l}487.8 \\
585.6\end{array}$ & $\begin{array}{l}0.096 \\
0.076\end{array}$ & $\begin{array}{l}0.090 \\
0.106\end{array}$ \\
\hline$(\text { Silastic } 44515)^{d}$ & $\begin{array}{l}\text { Black } \\
\text { White }\end{array}$ & $\begin{array}{r}8.9 \\
60.4\end{array}$ & $\begin{array}{r}9.5 \\
64.5\end{array}$ & $\begin{array}{l}490.2 \\
585.8\end{array}$ & $\begin{array}{l}489.0 \\
586.0\end{array}$ & $\begin{array}{l}0.102 \\
0.252\end{array}$ & $\begin{array}{l}0.120 \\
0.178\end{array}$ \\
\hline
\end{tabular}

a Contrast ratio at 0 and $900 \mathrm{~h} 0.11$ and 0.16

bContrast ratio at 0 and $300 \mathrm{~h} 0.08$ and 0.08 .

c Contrast ratio at 0 and $900 \mathrm{~h} 0.08$ and 0.09 .

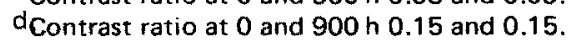

e $300 \mathrm{~h}$ of aging since samples disintegrated between this period and $600 \mathrm{~h}$. 
(vinyl chloride), an addition silicone and a heat-vulcanized silicone is shown in Table $6^{20}$. The samples were stained with tea, lipstick and Bismark Brown (disclosing solution) for $24 \mathrm{~h}$. Samples stained with tea or disclosing solution were washed and dried before colour measurements were made. Samples stained with a deep red shade of lipstick were wiped with a clean dry cloth and then cleansed with skin cream until no further stain was visible on the cloth after which they were washed and dried. The changes in luminous reflectance, dominant wavelength and excitation purity before and after removal of the staining agents showed that the three materials had individual staining characteristics. Silastic 44210 resisted staining with tea the best and had good resistance to staining by disclosing solution; it had the greatest change in dominant wavelength with lipstick. The changes in the three colour parameters were much larger than those observed during the aging of the base polymers or the pigmented maxillofacial material. These data confirm that environmental staining is more important than changes in colour from aging of maxillofacial appliances.

Table 5 Change in colour parameters of a pigmented silicone maxillofacial material after $900 \mathrm{~h}$ of accelerated aging

\begin{tabular}{llll}
\hline Pigment & $\begin{array}{l}\Delta \text { Luminous } \\
\text { reflectance }\end{array}$ & $\begin{array}{l}\Delta \text { Dominant } \\
\text { wavelength, } \mathrm{nm}\end{array}$ & $\begin{array}{l}\Delta \text { Excitation } \\
\text { purity }\end{array}$ \\
\hline White & -8.7 & 17.3 & 0.092 \\
Black & $-0.2^{*}$ & $-0.1^{*}$ & $0.006^{*}$ \\
Dark buff & -0.9 & $0.1^{*}$ & $0.006^{*}$ \\
Medium brown & -0.4 & $-0.1^{*}$ & 0.014 \\
Light brown & -0.6 & $-0.3^{*}$ & $0.001^{*}$ \\
Red brown & -0.3 & $-0.3^{*}$ & 0.014 \\
Red & $-0.1^{*}$ & -2.4 & $0.005^{*}$ \\
Light orange & -2.7 & -0.6 & -0.024 \\
Orange yellow & -12.3 & -2.7 & $-0.669^{*}$ \\
Yellow & -15.0 & $0.0^{*}$ & -0.757 \\
Blue & -0.4 & 0.7 & -0.008
\end{tabular}

* Difference not significant at the $95 \%$ level of confidence.

Table 6 Resistance of maxillofacial materials to various stains for a period of $24 \mathrm{~h}$

\begin{tabular}{llll}
\hline & $\begin{array}{l}\Delta \text { Luminous } \\
\text { reflectance }\end{array}$ & $\begin{array}{l}\Delta \text { Dominant } \\
\text { wavelength, nm }\end{array}$ & $\begin{array}{l}\Delta \text { Excitation } \\
\text { purity }\end{array}$ \\
\hline $\begin{array}{l}\text { Poly(vinyl chloride) } \\
\text { (Prototype III) } \\
\text { Tea }\end{array}$ & -2.8 & -2.6 & +0.040 \\
Lipstick & -5.5 & +18.9 & -0.002 \\
Bismark brown & -36.2 & +8.3 & +0.777 \\
& & & \\
Silicone & & & \\
(Silastic 44210) & & & \\
Tea & +0.6 & +0.8 & +0.007 \\
Lipstick & -5.9 & +26.5 & -0.003 \\
Bismark brown & -2.0 & -0.2 & +0.309 \\
(Silastic 44515) & & & \\
Tea & -1.2 & +0.1 & +0.026 \\
Lipstick & -6.9 & +22.7 & -0.042 \\
Bismark brown & -3.9 & 0.0 & +0.377 \\
\hline
\end{tabular}

A study of the cleansing of a stained addition silicone was reported by Yu et al. ${ }^{17}$. The samples were stained for $24 \mathrm{~h}$ by lipstick, Bismark Brown, and methylene blue. The stains were removed by swelling in the following solvents; toluene, benzene, 1,1,1-trichloroethane, or n-hexane for two days. The samples were deswollen by addition of methanol and then dried under vacuum to remove traces of solvents. The luminous reflectance, dominant wavelength, and excitation purity of the original, stained and cleansed (in n-hexane) samples are listed in Table 7 . The results with the other three solvents were comparable and thus only the values for $n$-hexane are shown. It is apparent that solvent extraction of the stains was highly effective. The change in the three colour parameters of the pigmented silicone after cleansing with $n$-hexane are shown in Table 8 . Negligible or no change in colour was observed in the pigmented samples after cleaning the samples, indicating stability of pigments after solvent extraction. Also, no significant change in dimensions, of hardness or tensile strength was found between the original and the cleansed samples. These results are encouraging in that the method may be adapted to the cleaning of maxillofacial prostheses that have become discoloured in a service environment.

Table 7 Effect of cleaning of stained silastic 44210 on colour parameters

\begin{tabular}{llll}
\hline Stain & $\begin{array}{l}\text { Luminous } \\
\text { reflectance }\end{array}$ & $\begin{array}{l}\text { Dominant } \\
\text { wavelength, } \mathrm{nm}\end{array}$ & $\begin{array}{l}\text { Excitation } \\
\text { purity }\end{array}$ \\
\hline $\begin{array}{l}\text { Lipstick } \\
\text { Original }\end{array}$ & 84.3 & 584.5 & 0.078 \\
Stained & 77.1 & 613.9 & 0.063 \\
Cleaned & 83.6 & 584.7 & 0.076 \\
Bismark brown & & & \\
Original & 83.9 & 584.6 & 0.078 \\
Stained & 77.7 & 584.4 & 0.596 \\
Cleaned & 84.4 & 584.5 & 0.081 \\
Methylene blue & & & \\
Original & 85.0 & 584.2 & 0.076 \\
Stained & 78.6 & 581.2 & 0.069 \\
Cleaned & 85.5 & 584.2 & 0.079 \\
\hline
\end{tabular}

Table 8 Change in colour parameters of pigmented silastic 44210 after extraction with n-hexane

\begin{tabular}{lllr}
\hline & $\begin{array}{l}\Delta \text { Luminous } \\
\text { reflectance }\end{array}$ & $\begin{array}{l}\Delta \text { Dominant } \\
\text { wavelength, nm }\end{array}$ & $\begin{array}{l}\Delta \text { Excitation } \\
\text { purity }\end{array}$ \\
\hline White & -0.5 & +1.7 & +0.029 \\
Black & -0.1 & +0.5 & 0.000 \\
Dark buff & -0.4 & +0.1 & +0.001 \\
Medium brown & -0.1 & +0.1 & 0.000 \\
Light brown & -0.5 & +0.2 & +0.003 \\
Red brown & 0.2 & +0.2 & +0.002 \\
Red & 0.0 & +0.1 & -0.012 \\
Light orange & +0.1 & +0.2 & 0.000 \\
Orange yellow & -0.3 & +0.1 & -0.001 \\
Yellow & -0.4 & 0.0 & +0.001 \\
Blue & -0.1 & +0.2 & 0.000 \\
\hline
\end{tabular}

\section{Current status and future developments}

Ease of manipulation and processing favour the selection of a room temperature polymerized silicone which can be processed in an easily constructed gypsum mould. Silicones of the 44210 type have the advantage over the 382 and 399 types as well as the silphenylene type in that no volatile by-product is formed during polymerization and thus the former are more dimensionally accurate. The processing of the poly(vinyl chloride) materials is exacting and metal moulds must be used because of the high processing temperatures required. The proportioning of the components of the polyurethanes is highly critical since the reaction is stoichiometric and no residual isocyanate groups should remain since they are very toxic. For this reason, the 
diisocyanates must be handled with caution. The polyurethane must be processed under dry conditions and metal moulds are required. The processing of chlorinated poly. ethylene is done at high temperatures in a metal mould.

Although the room-temperature polymerized silicone 44210 did not have as high static mechanical properties as the experimental polyurethane and the chlorinated polyethylene, the values are similar and more than adequate. The stability of the dynamic modulus of silicone 44210 as a function of temperature is also desirable in a service environment since it will have the same stiffness at very low and high temperatures.

Properly stabilized maxillofacial polymers show minor changes in colour with accelerated aging. Pigmented polymers also show no major changes in colour although specific white and yellow pigments may demonstrate small changes in colour as a function of time of aging. The large changes in appearance of maxillofacial prostheses results from staining as a result of environmental stains, body oils, or cosmetics applied by the patient.

Highly crosslinked polymers such as the silicone 44210 can be cleaned by solvent extraction without altering the physical and mechanical properties. This type of cleaning is not possible with the plasticized poly (vinyl chloride) or the chlorinated polyethylene. Solvent cleaning techniques will add to the service life and aesthetics of the prosthesis.

Additional information needed to improve maxillofacial materials is further definition of the mechanical properties of human tissues with respect to their elastic and viscoelastic properties. This information should permit a better matching of the properties of the prosthesis to the tissues which it is replacing.

The range of colours of the face have been reasonably well documented by reflection spectrophotometry. It should now be possible to formulate the matching base colour for a prosthesis by measuring the skin colour of a patient with a spectrophotometer and subsequently using a computer program to specify the ratio of specific pigments and elastomer to match the specific skin colour. The application of this information should result in improved aesthetics after final characterization of the prosthesis with a considerable saving of clinic time.

Another area of investigation which should receive attention is a study of adhesives and their effects upon the tissues and the maxillofacial materials.

It is apparent that based on existing knowledge, room temperature polymerized silicone polymers of the addition type (44210 being a commercial example) offer optimum overall properties for maxillofacial applications.

\section{ACKNOWLEDGEMENT}

The authors acknowledge support for part of the research reported in this paper from a USPHS Research Grant DE-04136 from the National Institute for Dental Research, National Institutes of Health, Bethesda, MD 20014.

\section{REFERENCES}

1 Cantor, R., Webber, R.L., Stroud, L. and Ryge, G., J. Prosth. Dent. 1969, 21, 324

2 Walter, J.D., Dent. Practit. Dent. Record 1970, 20, 208

3 Roberts, A.C., Dent. Practit. Dent. Record 1971, 21, 276

4 Sweeney, W.T., Fisher, T.E., Castleberry, D.J. and Cowperthwaite, G.F., J. Prosth. Dent. 1972, 27, 296

5 Wachtel, L.W., (Ed.) 'Proceedings Symposium - Dental Biomaterials - Research priorities', Department of Health Education Welfare Publication No. (NIH) 74-548, Washington, D.C., $1974,275 \mathrm{pp}$

6 Castleberry, D.J., 'Proceedings Symposium - Dental Biomateria/s - Research Priorities', Department of Health Education Welfare Publication No. (NIH) 74-548, Washington, D.C., 1974, p 25562

7 Lontz, J.F., Schweiger, J.W. and Berger, A.W., J. Dent. Res. Spec. Iss. 1974, 53, 277

8 Koran, A. and Craig, R.G., J. Dent. Res. 1975, 54, 1216

9 Goldberg, A.J., 'Polyurethane Elastomers as Maxillofacial Prosthetic Materials', Doctoral Dissertation, University of Michigan, Ann Arbor, 1977, $194 \mathrm{p}$

10 Goldberg, A.J., Craig, R.G. and Filisko, F.E., J. Dent. Res. Spec. Iss. A 1977, 56. A173; and Dental Materials Group Microfilm, IADR, Copenhagen, 1977, paper 523

11 Goldberg, A.J., Craig, R.G. and Filisko, F.E., J. Dent. Res. $1978,57,563$

12 Yu, R., Koran, A. and Craig, R.G., J. Dent. Res. Spec. Iss. B 1977, 56, B150; and Dental Materials Group Microfilm AADR, Las Vegas, 1977, paper 392.

13 May, P., Guerra, L.R. and Rauls, H.R., J. Dent. Res. Spec. Iss. B 1977, 56, B150; and Dental Materials Group Microfilm, AADR, Las Vegas, 1977, paper 394

14 Gonzalez, J.B., J. Prosth. Dent. 1978, 39, 179

15 Yu, R., Koran, A. and Craig, R.G., J. Dent. Res. Spec. Iss. A 1978, 57, 295; and Dental Materials Group Microfilm, IADR, Washington, D.C., 1978, paper 881

16 Craig, R.G., Koran, A., Yu, R. and Spencer, J., J. Dent. Res. $1978,57,866$

17 Yu, R., Koran, A., Raptis, C.N. and Craıg, R.G., J. Dent. Res. Spec. Iss. A 1979, 58, 360

18 Koran, A., Powers, J.M., Raptis, C.N. and Yu, R., J. Dent Res. Spec. Iss. A 1979, 58, 360

19 Koran, A., Yu, R., Powers, J.M. and Craig, R.G., J. Dent. Res. $1979,58,1450$

20 Koran, A., Powers, J.M., Lepeak, P.J. and Craig, R.G., J. Dent. Res. $1979,58,1455$

21 King, A.L. and Lawton, R.W., 'Elasticity in Body Tissues', in 'Medical Physics', (Ed. O. Glasser) Vol. II, Year Book Publishers, Chicago, 1950, p 303

22 Sten-Knudsen, O., Acta Physiol. Scand. 1953, 28, Suppl. 104 23 Seluk, L.W., Yu, R. and Koran, A., J. Dent. Res. Spec. Iss. A $1979, \mathbf{5 8}, 361$ 